\title{
Geochemical characteristics and genetic model of dolomite reservoirs in the eastern margin of the Pre-Caspian Basin
}

\author{
Wang Shuqin ${ }^{1,2 *}$, Zhao Lun ${ }^{2}$, Cheng Xubin ${ }^{3}$, Fan Zifei ${ }^{2}$ and He Ling ${ }^{2}$ \\ ${ }^{1}$ School of Energy Resources, China University of Geosciences, Beijing 100083, China \\ ${ }^{2}$ Research Center of Central Asia and Russia, Institute of Petroleum Exploration \& Development, PetroChina, Beijing \\ 100083, China \\ ${ }^{3}$ Institute of Geological Exploration \& Development, PetroChina Chuanqing Drilling Engineering Company Limited, \\ Sichuan 610051, China
}

(C) China University of Petroleum (Beijing) and Springer-Verlag Berlin Heidelberg 2012

\begin{abstract}
The widespread Carboniferous KT-I dolomite in the eastern margin of the Pre-Caspian Basin is an important hydrocarbon reservoir. The dolomite lithology is dominated by crystalline dolomite. The $\delta^{18} \mathrm{O}$ values range from $-6.71 \%$ to $2.45 \%$, and average $0.063 \%$, obviously larger than $-2.5 \%$, indicating low-temperature dolomite of evaporation origin. Stable strontium isotope ratios $\left({ }^{87} \mathrm{Sr} r{ }^{86} \mathrm{Sr}\right)$ range from 0.70829 to 0.70875 and average 0.708365 , very consistent with ${ }^{87} \mathrm{Sr} /{ }^{86} \mathrm{Sr}$ ratios in Carboniferous seawater. Chemical analysis of $\mathrm{Ca}$ and $\mathrm{Mg}$ elements shows that the dolomite has $9.1 \mathrm{~mole} \%$ excess $\mathrm{Ca}$ or even higher before stabilization. The degree of order of dolomite is medium-slightly poor, varying in a range of 0.336-0.504 and averaging 0.417. It suggests that the dolomite formed under near-surface conditions. There are two models for the origin of the Carboniferous KT-I dolomite reservoir. These are 1) the evaporation concentration - weathering crust model and 2) the shoal facies - seepage reflux model. The former is mainly developed in restricted platforms - evaporate platforms of restricted marine deposition environments with a representation of dolomite associated with gypsum and mudstone. The latter mainly formed in platform edge shoals and intra-platform shoals and is controlled by dolomitization due to high salinity sea water influx from adjacent restricted sea or evaporate platform.
\end{abstract}

Key words: Isotope, dolomite, Carboniferous, genetic model, eastern margin of Pre-Caspian Basin

\section{Introduction}

The Pre-Caspian Basin is one of the deepest subsidence basins in the world and also a major petroliferous basin. With the Permian Kungurian salt as a boundary, the basin can be divided into two structural sequences vertically: pre-salt and post-salt sequences. In the exploration of the post-salt Carboniferous carbonate reservoirs, a series of large/huge-scale oilfields (e.g. Astrakhan Gasfield, Tengiz Oilfield, Karachanag Oilfield, and Zhanazhol Oilfield) were discovered, in which the middle-upper Carboniferous dolomite reservoirs mainly have high productivity, with a daily oil output rate of single well up to more than $500 \mathrm{t} / \mathrm{d}$. Due to the control of three geological factors, deposition, diagenesis and structure, dolomite reservoir development has varied in different basin areas. In this paper, taking the eastern margin of the Pre-Caspian Basin as an example, we discuss

*Corresponding author. email: wshuqin@petrochina.com.cn Received November 28, 2011 the genetic model of dolomite reservoirs based on a great deal of core observation and test data.

\section{Geology in the study area}

Tectonically, the Pre-Caspian Basin lies in the southeast of the Eastern European Platform. As a superimposed basin formed during the Late Proterozoic Era, the basin presents a fault terrace (in the west and north) and a gentle slope (in the east and southeast) subsiding gradually from basin edge towards basin center, characterized by an asymmetrical structure deep in the north and shallow in the south. There is a series of uplift zones around the central depression belt of the basin. The distribution of large oilfields in the presalt sequence is closely related to continental shelf facies carbonate organic buildup in the uplift tectonic units of the basin margin. The Enbeksk-Zharamysskaya Uplift Zone is an important hydrocarbon-bearing uplift zone in the eastern margin of the basin. The Zhanazhol and North Truva Oilfields in the study are located in the middle part of the uplift zone (Fig. 1). 


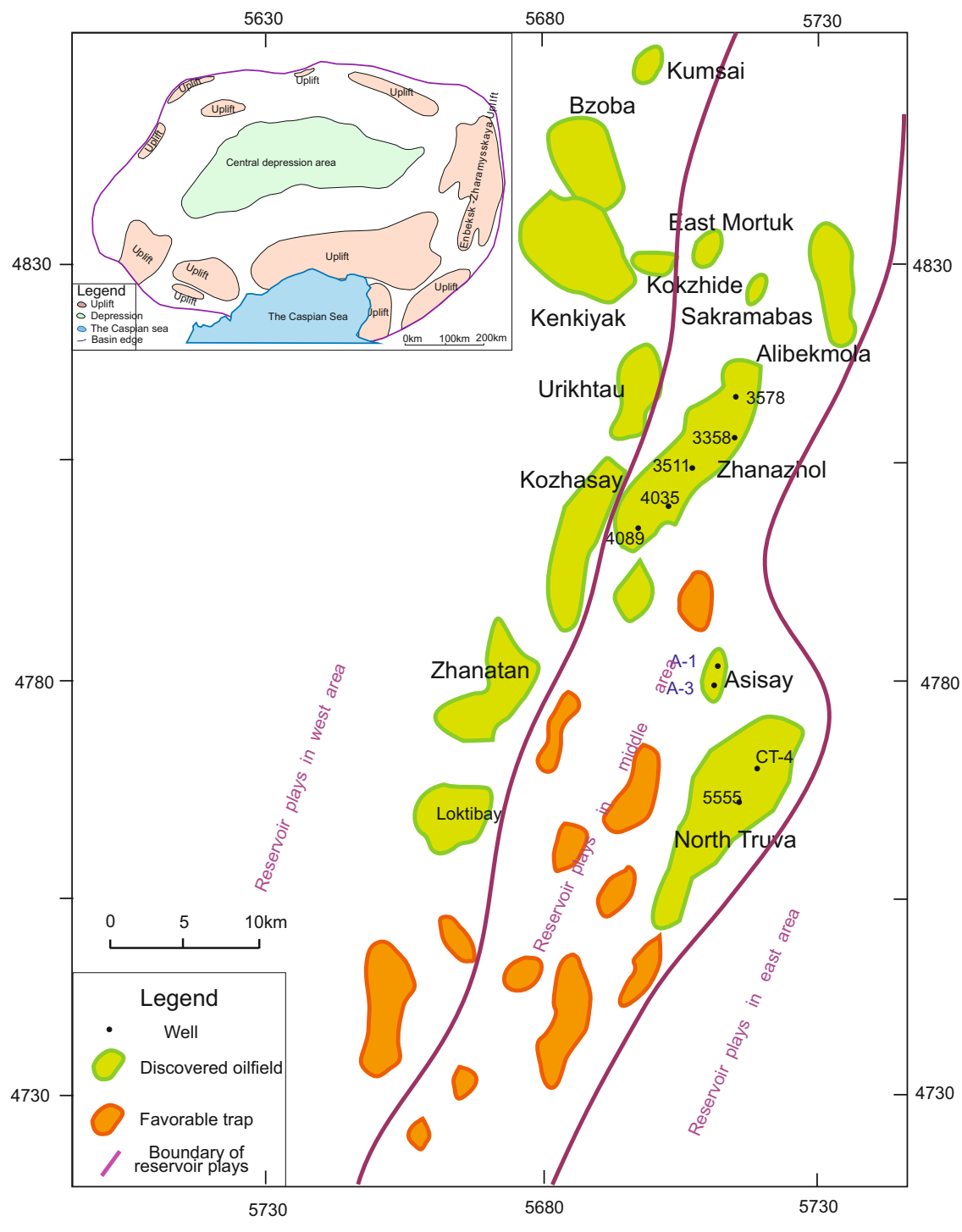

Fig. 1 Regional location of the study area

The Late Carboniferous in the study area is situated in the eastern margin of the Eastern European Platform. It is a shallow marine carbonate platform, adjacent to the Ural Trough in the east. A set of KT-I carbonate sequences developed on the platform, also called "the Upper Carbonate Buildup of the Carboniferous". Vertically, the KT-I formation is composed of three zones (A, Б and B), with a thickness of 328-450 m, judged as a set of limestone-dolomite-gypsum buildups of a shallowing-upward sequence. The lithology of the study area varies vertically and laterally. In the Zhanazhol Oilfield in the north, besides decreasing dolomite and gypsum contents and increasing limestone content from north to south, the formation lithology evolves from gypsum, dolomite and gypsodolomite to calcite dolomite, dolomitic limestone and limestone. In the Asisay and North Truva regions to the south of the Zhanazhol Oilfield, the two lower zones of $\mathrm{B}$ and $\mathrm{B}$ are mainly composed of dolomitic limestone and limestone. The A Zone on the top of the Asisay formation is mainly composed of thin gray gypsum with calcite dolomite and dolomitic mudstone. In the North Truva region, dolomite content increases upwards, and the formation top is mainly composed of calcite dolomite and dolomite with a thickness of 5-26 m (Fig. 2). The dolomite thickness in the study area varies laterally. Taking the A3 Zone as an example, the dolomite formation through the Zhanazhol Oilfield has a larger thickness trending from northwest to southeast, averaging above $15 \mathrm{~m}$, and the lateral dolomite layers nip out before disappearing. In the North Truva Oilfield, dolomite appears from south to north of CT47-CT25, with a thickness of 15-25 m, and reduces towards surrounding areas. The dolomite thickness is below $5 \mathrm{~m}$ between North Truva Oilfield and Zhanazhol Oilfield (Fig. 3).

\section{Petrological characteristics of dolomite}

The analysis of dolomite chemical compositions in the study area shows an average of $31.3 \%$ calcium oxide, $19.2 \%$ magnesium oxide and $2.9 \%$ acid insoluble. 125 dolomite samples (thin-section), have an average mineral composition of $94.9 \%$ dolomite, $2.6 \%$ calcite and $1.4 \%$ clay as well as minor authigenic siliceous cements, pyrite, gypsum and kaolinite.

The dolomite in the study area was classified in terms of petrological characteristics, in which granular dolomite, 


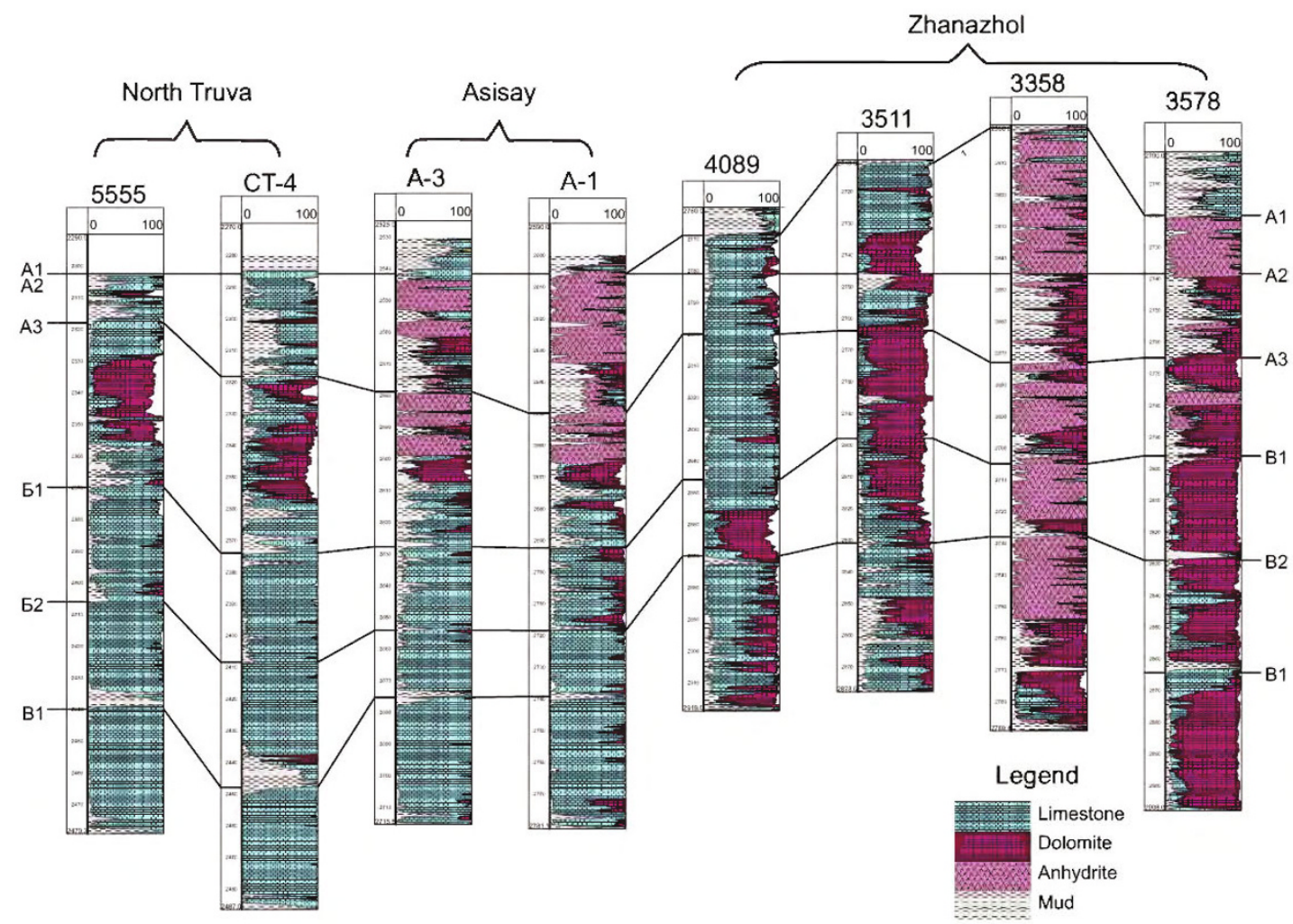

Fig. 2 Lithologic section of the eastern margin of Pre-Caspian Basin

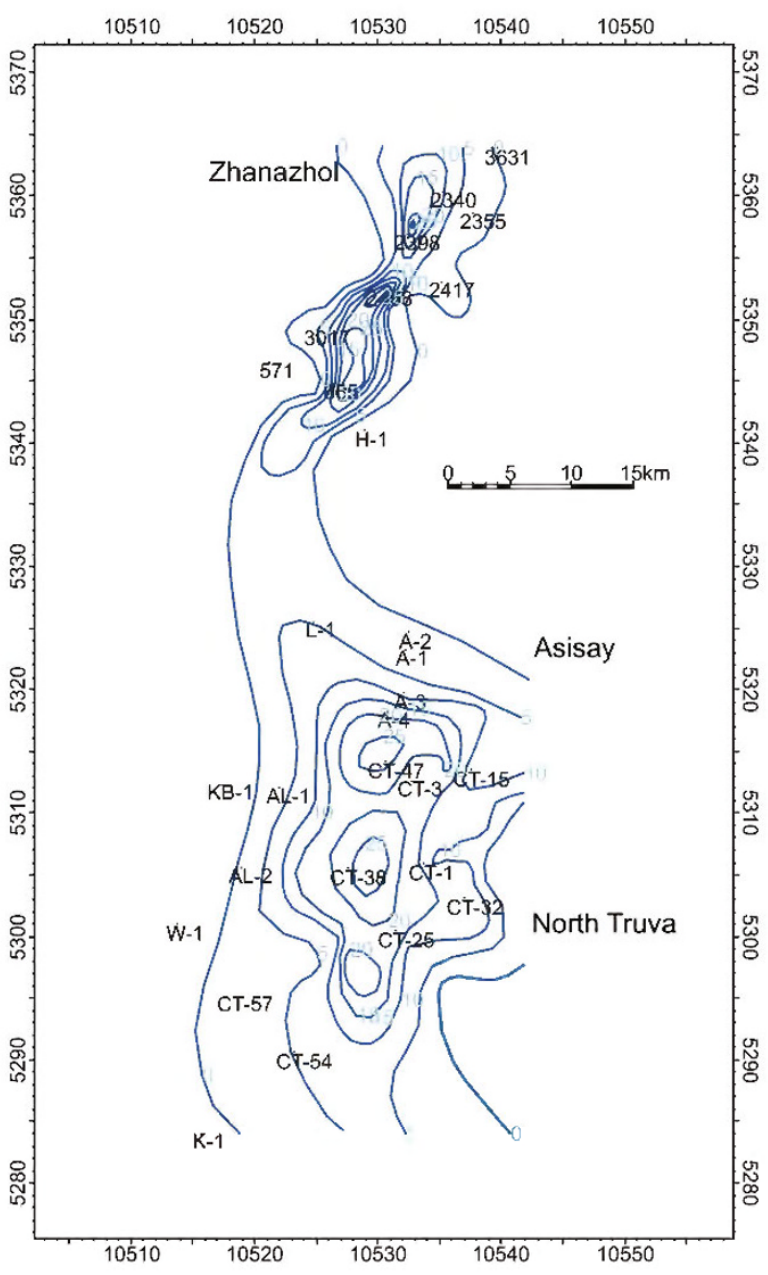

Fig. 3 Dolomite thickness layout of A3 Zone in the eastern margin of Pre-Caspian Basin crystalline dolomite and other dolomites account for $16.8 \%$, $77.6 \%$ and $5.6 \%$ respectively. Granular dolomites are all of biogenetic origin and mainly made up of bioclastic dolomite $(9.6 \%)$. In crystalline dolomite, crystalline powder dolomite and micritic-crystalline powder dolomite account for $48.8 \%$, and micritic dolomite accounts for $28.8 \%$ (Fig. 4).

Crystalline dolomite has an average particle content of $29.3 \%$, in which bio-particle, non-biological particle and mud-supported particle account for $28.4 \%, 0.9 \%$ and $70.7 \%$ respectively. Granular dolomite has an average particle content of $66.9 \%$, in which bio-particle, non-biological particle and micrite interstitial matter account for $66.7 \%, 0.3 \%$ and $33.1 \%$ respectively. The skeletal detritus of both dolomite types are controlled by foraminifera, fusulinids and bioclast (Table 1).

\section{Isotopic characteristics of elements carbon and oxygen}

Carbon and oxygen isotopes of the Carboniferous seawater have been measured by many researchers (Popp et al, 1986; Lohmann and Walker, 1989; Allan and Wiggins, 1993). Based on carbon and oxygen isotope assay of the Carboniferous seawater cements and invertebrate fossils, $\delta^{18} \mathrm{O}$ and $\delta^{13} \mathrm{C}$ values range from $-2 \%$ to $-1 \%$ and from $3.1 \%$ to $4.7 \% 0$ respectively.

Using an MAT251 isotope mass spectrometer, we measured carbon and oxygen isotopes ratios for 22 dolomite samples from Zhanazhol and North Truva Oilfields. The results are shown in Table 2 . The $\delta^{18} \mathrm{O}$ values range from $-6.71 \%$ to $2.45 \%$, averaging $0.063 \%$. The plot for carbon and oxygen isotopes of dolomite largely covers the area where the $\delta^{18} \mathrm{O}$ is above $-1 \%$, greater than that in Carboniferous seawater. So the samples are composed of low temperature 


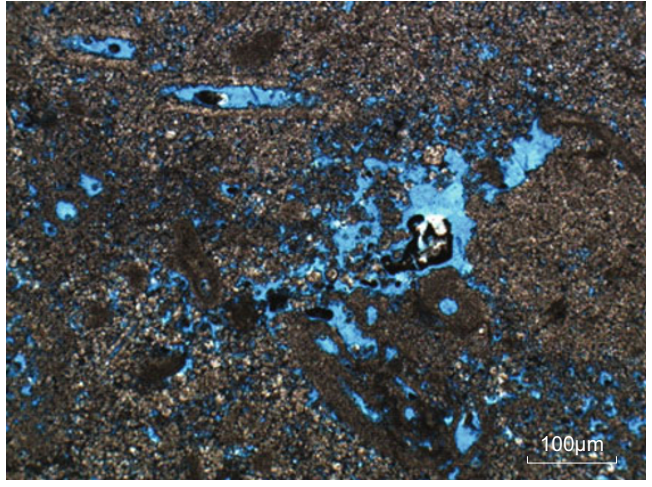

Well CT-4, 2350.14-2350.17 m

Residual foraminifera crystalline powder dolomite

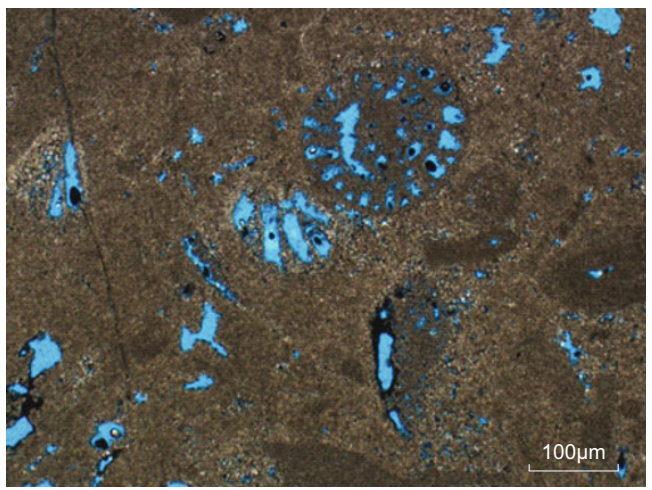

Well CT-4, 2344.40-2344.43 m

Crystalline powder bioclast dolomite

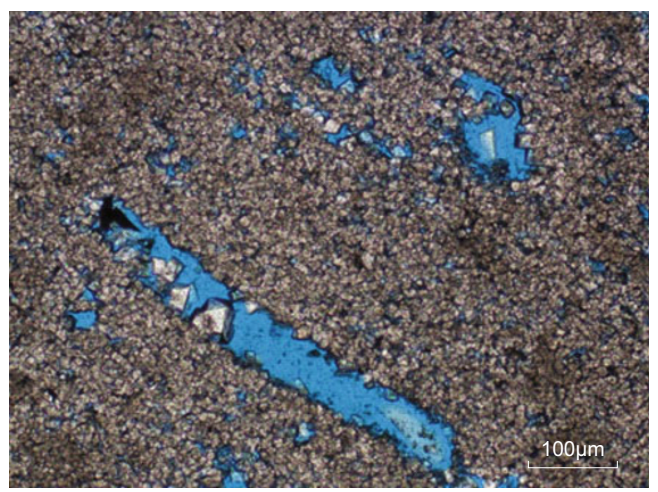

Well CT-22, $2371.12 \mathrm{~m}$

Micritic-crystalline powder dolomite

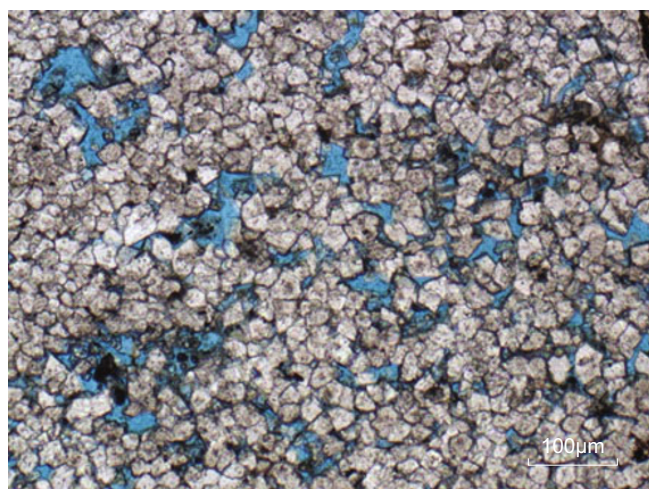

Well CT-4, $2335.52 \mathrm{~m}$

Coarse crystalline powder dolomite

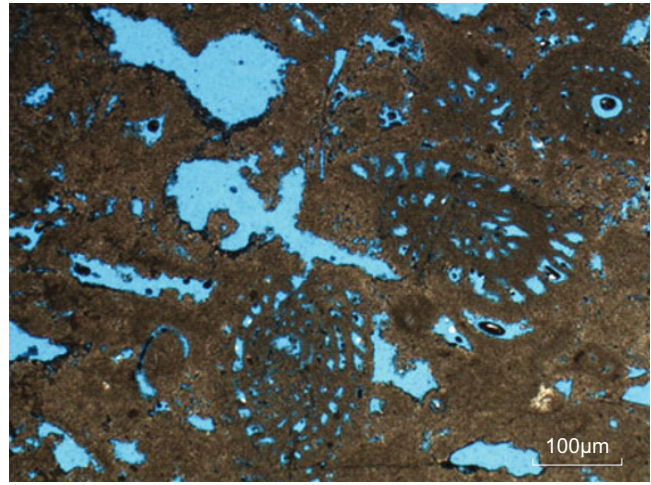

Well CT-4, 2341.44-2341.47 m

Micritic bioclast and fusulinid dolomite

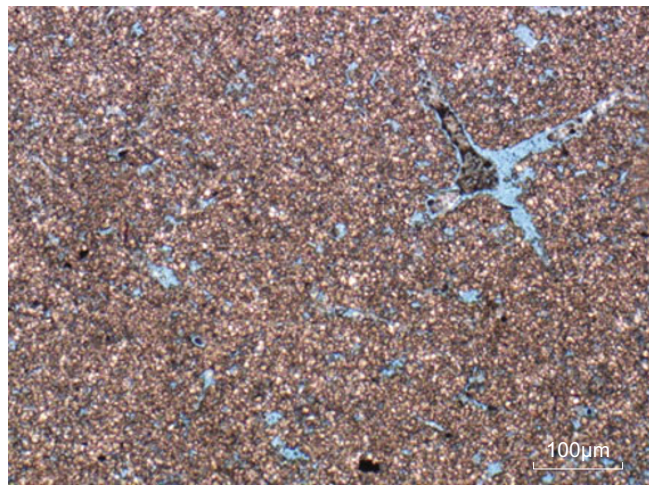

Well CT-4, 2324.72-2324.75 m

Micritic dolomite

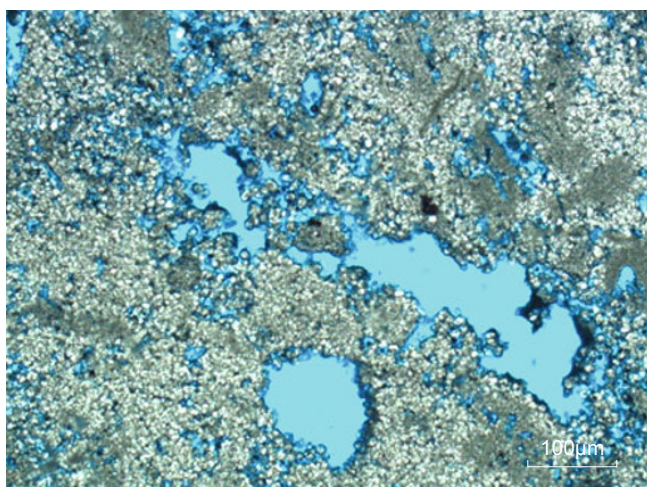

Well 5555, $2331.97 \mathrm{~m}$

Residual foraminifera crystalline powder dolomite

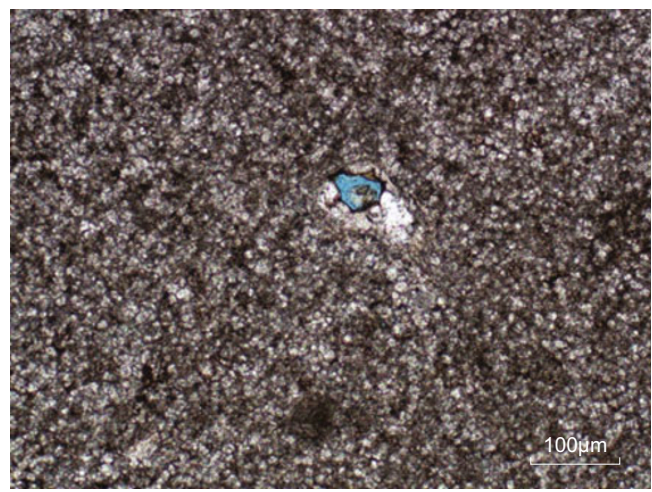

Well CT-22, $2373.06 \mathrm{~m}$

Micritic-crystalline powder calcareous dolomite

Fig. 4 Dolomite characteristics in the eastern margin of the Pre-Caspian Basin 
Table 1 Statistical structural compositions of KT-I dolomites in the eastern margin of the Pre-Caspian Basin

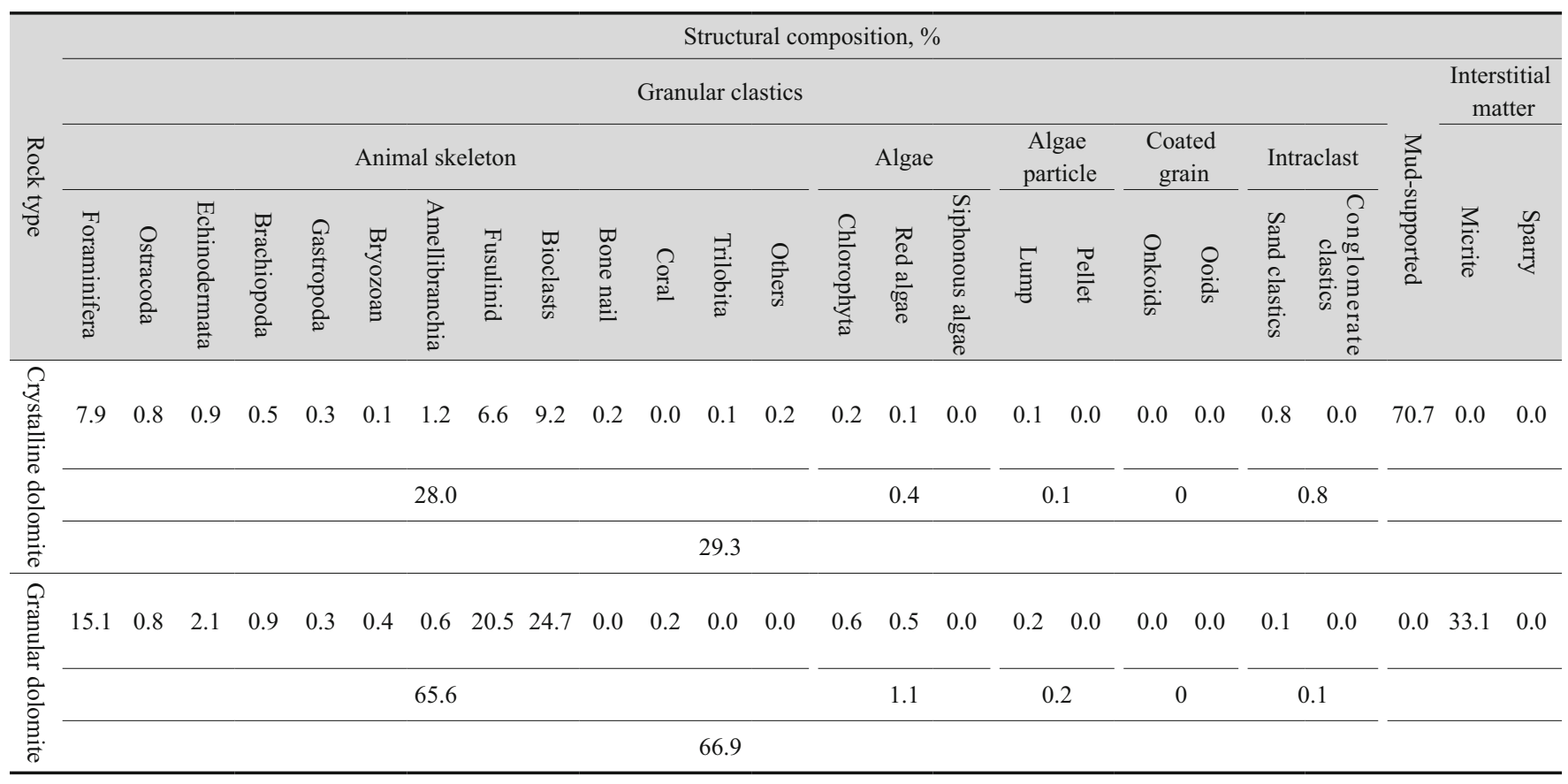

dolomites from evaporation-related penecontemporaneous and reflux dolomitization (Fig. 5). The ${ }^{16} \mathrm{O}$ isotope is relatively light. Water with ${ }^{16} \mathrm{O}$ is a little more likely to evaporate than water with the slightly heavier ${ }^{18} \mathrm{O}$ isotope. Together with increasing salinity, the remaining seawater also begins to accumulate ${ }^{18} \mathrm{O}$. When penecontemporaneous dolomitization or reflux dolomitization occurs, dolomite was formed by metasomatic alternation of carbonate deposits due to the high salinity water with heavier ${ }^{18} \mathrm{O}$ isotope. So the dolomite has a higher $\delta^{18} \mathrm{O}$ value than that of seawater. Low temperature dolomite, formed in supratidal, sabkha, reflux, sea and fresh water-sea water mixing environments in near surface areas, generally has a $\delta^{18} \mathrm{O}$ value over $-6.5 \%$ (Lü et al, 2005; Guo et al, 2004). Among the samples, only one has a $\delta^{18} \mathrm{O}$ value of $-6.715 \%$, suggesting local formation of high temperature burial dolomite with the growth of burial depth and temperature. In burial conditions, the temperature increases continually with increasing burial depth. Owing to thermal action and dolomitization, the relatively heavy ${ }^{18} \mathrm{O}$ enters metasomatic fluids, and relatively light ${ }^{16} \mathrm{O}$ enters the metasomatic dolomite lattice. That is so-called "temperature effect" or "thermal action effect" in isotope dynamic fractionation. High temperature dolomite is defined to be formed by dolomitization under burial conditions at a temperature greater than $50^{\circ} \mathrm{C}$. It also acts as cement to fill intergranular spaces, dissolved cavities and fissures, and its $\delta^{18} \mathrm{O}$ value is generally smaller than $-2.5 \%$ (Franchi et al, 1986; Luo et al, 2006; Peng et al, 2001).

Although carbon isotope ratios in dolomite have a limited effect on dolomite genesis (Powell and Kyser, 1991; Smith, 2006), when burial dolomitization occurs, stable carbon isotopes in the dolomite are affected by organic carbon. In the study area, dolomite $\delta^{13} \mathrm{C}$ values range from $-1.6 \%$ to $5.94 \%$ and average $4.48 \%$, much similar to the stable carbon isotope ratio of Carboniferous seawater and the value is slightly positive, showing it is unaffected by burial.
Table 2 Measurement results of isotopes

in dolomite of the eastern margin of Pre-Caspian Basin

\begin{tabular}{|c|c|c|c|c|c|}
\hline Oilfield & $\begin{array}{l}\text { Well } \\
\text { No. }\end{array}$ & $\begin{array}{c}\text { Depth } \\
\mathrm{m}\end{array}$ & Lithology & $\begin{array}{c}\delta_{\%}^{13} \mathrm{C} \\
\%\end{array}$ & $\begin{array}{c}\delta^{18} \mathrm{O} \\
\% 0\end{array}$ \\
\hline \multirow{5}{*}{$\begin{array}{c}\text { Zhanazhol } \\
\text { Oilfield }\end{array}$} & 2092 & 2813.39 & Calcareous dolomite & 2.1 & -0.41 \\
\hline & 2092 & 2814.85 & Calcareous dolomite & -1.6 & 0.47 \\
\hline & 2092 & 2817.21 & Calcareous dolomite & 2.62 & -0.92 \\
\hline & 2092 & 2841.31 & Calcareous dolomite & 3.48 & -6.71 \\
\hline & 5555 & 2335.62 & Micritic dolomite & 5.3 & -0.13 \\
\hline \multirow{17}{*}{$\begin{array}{l}\text { North } \\
\text { Truva } \\
\text { Oilfield }\end{array}$} & 5555 & 2331.66 & $\begin{array}{c}\text { Crystalline powder } \\
\text { dolomite }\end{array}$ & 4.25 & -0.2 \\
\hline & 5555 & 2341.45 & $\begin{array}{c}\text { Crystalline powder } \\
\text { dolomite }\end{array}$ & 5.27 & 0.98 \\
\hline & 5555 & 2345.69 & $\begin{array}{c}\text { Crystalline powder } \\
\text { dolomite }\end{array}$ & 5.94 & 2.31 \\
\hline & 5555 & 2336.98 & Micritic dolomite & 5.34 & 0.05 \\
\hline & 5555 & 2345 & $\begin{array}{c}\text { Crystalline powder } \\
\text { dolomite }\end{array}$ & 5.26 & -1.06 \\
\hline & 5555 & 2354 & $\begin{array}{c}\text { Crystalline powder } \\
\text { dolomite }\end{array}$ & 5.61 & 1.03 \\
\hline & 5555 & 2332.48 & Micritic dolomite & 4.61 & -0.15 \\
\hline & 5555 & 2337.5 & Micritic dolomite & 5.37 & -0.72 \\
\hline & 5555 & 2341.78 & Micritic dolomite & 5.53 & 0.86 \\
\hline & 5555 & 2345.98 & $\begin{array}{c}\text { Crystalline powder } \\
\text { dolomite }\end{array}$ & 5.78 & 2.3 \\
\hline & 5555 & 2340.94 & Micritic dolomite & 5.94 & 2.45 \\
\hline & 5555 & 2333.88 & Micritic dolomite & 4.96 & 0.29 \\
\hline & 5555 & 2347.14 & Micritic dolomite & 5.39 & 0.1 \\
\hline & 5555 & 2343.81 & Micritic dolomite & 5.38 & -0.08 \\
\hline & CT-4 & 2347.53 & $\begin{array}{c}\text { Crystalline powder } \\
\text { dolomite }\end{array}$ & 3.82 & 0.38 \\
\hline & CT-4 & 2344.08 & $\begin{array}{c}\text { Crystalline powder } \\
\text { dolomite }\end{array}$ & 4.89 & 0.63 \\
\hline & CT-4 & 2351.49 & $\begin{array}{c}\text { Crystalline powder } \\
\text { dolomite }\end{array}$ & 3.36 & -0.08 \\
\hline
\end{tabular}




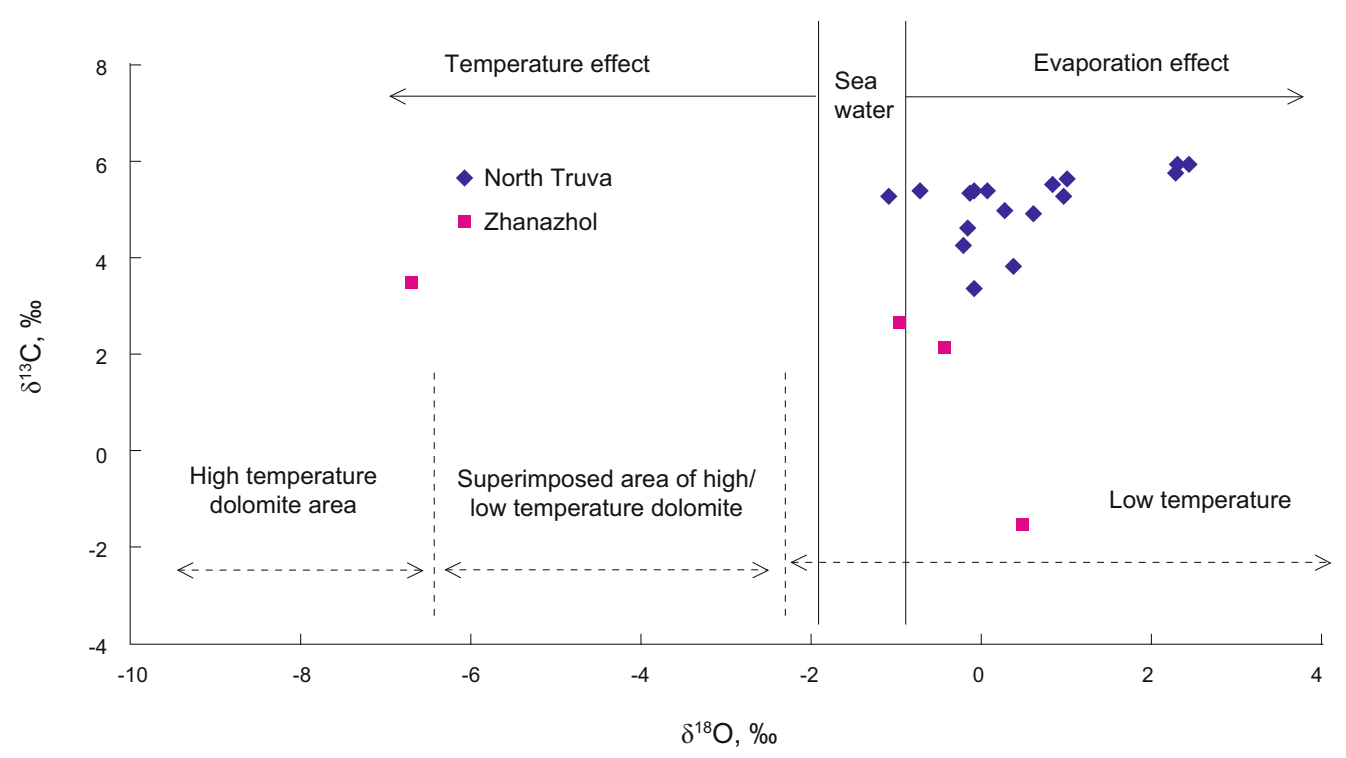

Fig. 5 Distribution of carbon and oxygen isotopes in dolomite of the eastern margin of the Pre-Caspian Basin

\section{Strontium isotopic characteristics}

According to related study results (Allan and Wiggins, 1993; Burke et al, 1982; Palmer and Elderfield, 1985), ${ }^{87} \mathrm{Sr} /{ }^{86} \mathrm{Sr}$ ratios in Carboniferous seawater range from 0.708265 to 0.708750 and average 0.708365 . Strontium stable isotope data of KT-I dolomite show that ${ }^{87} \mathrm{Sr} /{ }^{86} \mathrm{Sr}$ ratios range from 0.70829 to 0.70875 and average 0.708365 (Fig. 6), very consistent with those of the Carboniferous seawater.

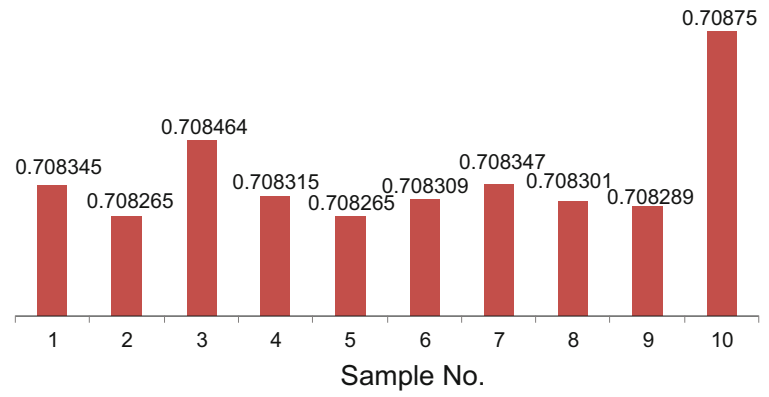

Fig. 6 Distribution of ${ }^{87} \mathrm{Sr} /{ }^{86} \mathrm{Sr}$ ratios in dolomite from the North Truva Oilfield

\section{Stoichiometry and degree of order of dolomite}

Stoichiometry and degree of order of dolomite are two important parameters in judging dolomite genesis. Due to the effect of dynamic factors, a majority of the Holocene and modern dolomites have a high $\mathrm{Ca}$ content and relatively low degree of order with very weak X-ray diffraction (XRD) reflections. Generally, the Holocene dolomite has excessive Ca content of above 8 mole\% (Land, 1982) and low degree of order which will be enhanced to some degree in the stabilization process. Under burial conditions, increased temperature can overcome the dynamic barrier. The dolomite has high degree of order and strong XRD reflections (Deng et al, 2005; Wang and Chen, 1993; Qiang et al, 1996).

$\mathrm{Ca}$ and $\mathrm{Mg}$ analysis for 42 dolomite samples collected in the study area, showed the average content of $\mathrm{Mg}$ and $\mathrm{Ca}$ is $12.1 \%$ and $22.0 \%$ respectively, and converted to dolomite, the average excess $\mathrm{Ca}$ content is as high as $9.1 \mathrm{~mole} \%$ and even higher prior to the stabilization process.

The analysis data of dolomite degree of order in the study area (Fig. 7) show that the degree of order of dolomite ranges from 0.336 to 0.504 and average 0.417 , indicating a medium to slightly poor degree of order. The value may be higher than that of dolomite not yet stabilized. Compared with the degree of order of burial dolomite (or hydrothermal dolomite) which ranges from 0.7 to 1.0 (Zhang, 2000; Warren, 2000), the Carboniferous KT-I dolomite has a low degree of order ranging from 0.336 to 0.504 . It indicates that the dolomite is formed in the near surface areas, namely evaporation and reflux conditions.

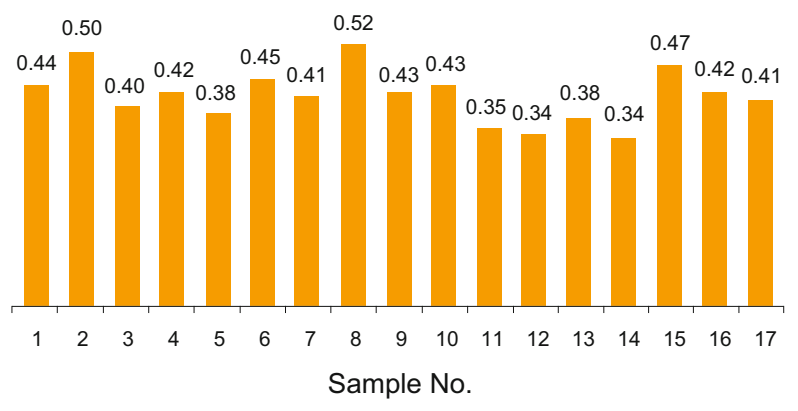

Fig. 7 Distribution of dolomite degree of order in North Truva Oilfield

\section{Genetic model of dolomite reservoir in the study area}

From comprehensive analysis of regional structure, sedimentation and diagenesis, two models are proposed for the genesis of the Carboniferous KT-I: 1) the evaporation concentration - weathering crust model and 2) shoal facies - 
seepage reflux model.

\subsection{Dolomite of the evaporation concentration - weathering crust model}

During the early and middle part of the late Carboniferous period, the study area was dominated by normal deposition of open platform facies marine carbonate. Until the late of the period, frequent crustal rise and fall occurred due to the Hercynian movement, and most of the study area was located in a restricted marine deposition environment of restricted platforms - evaporate platforms (Fig. 8). In the east of the Zhanazhol Oilfield, and large part of the Asisay and North Truva Oilfields, restricted platform lagoon microfacies and evaporation platform tidal microfacies developed, representing an interbedded structure of dolomite and gypsum with occasional calcareous matter. The gypsum formation is 0.7-21 $\mathrm{m}$ thick and the dolomite formation, developed under the effect of penecontemporaneous capillary evaporation concentration dolomitization, is $1.2-11 \mathrm{~m}$ thick (Zhao et al, 2009). The dolomite lithology includes dolomicrite, crystalline powder dolomite and gypsum-bearing dolomite (Fig. 9).

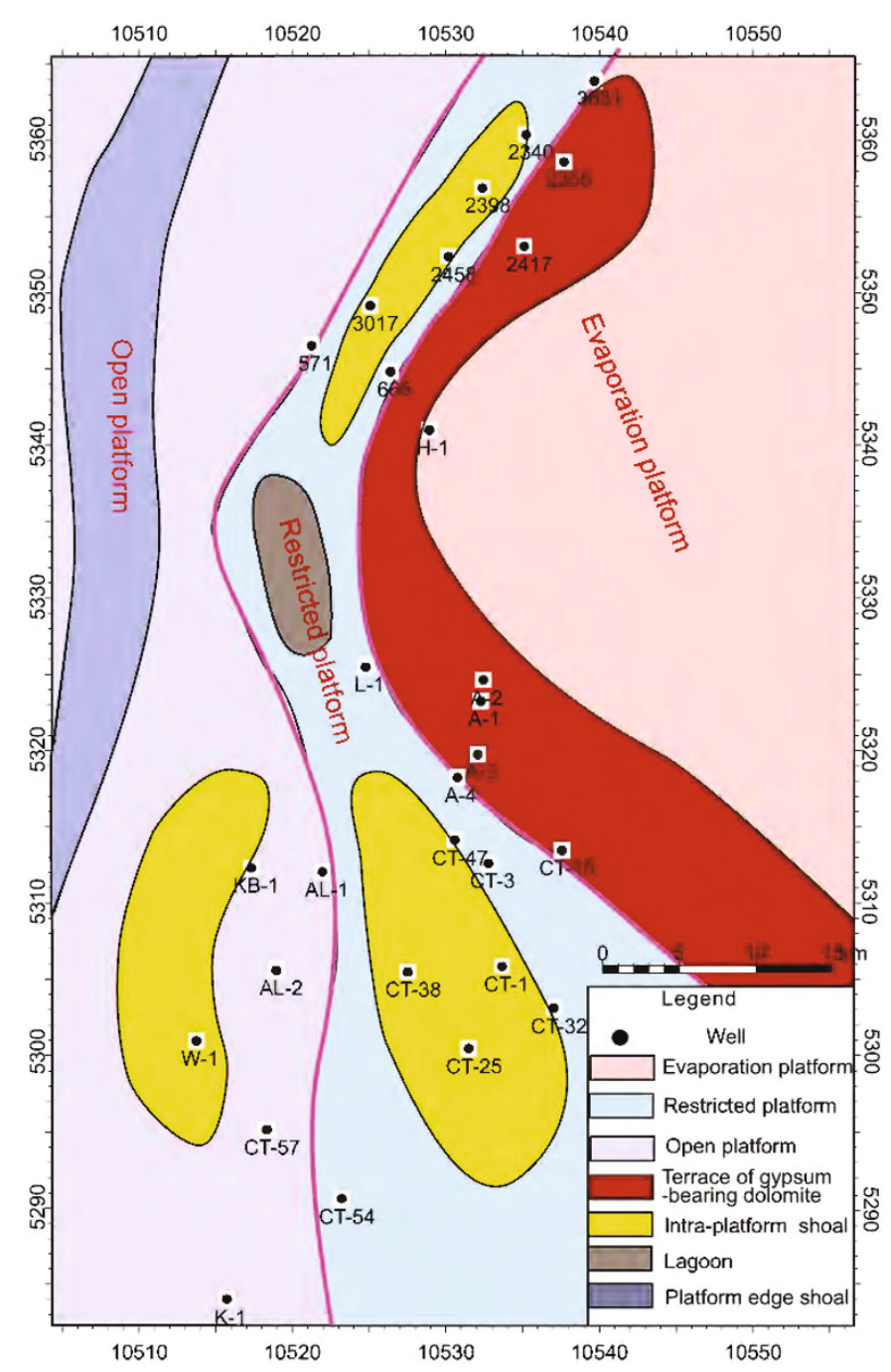

Fig. 8 Layout of the A3 Zone sedimentary facies in the eastern margin of the Pre-Caspian Basin
In the late Carboniferous, tectonic movement caused an abrupt crustal rise. The upper formations formed during that period underwent weathering and denudation. Zone A1 and A2 and partial A3 are absent commonly in the North Truva Oilfield. When the rocks experienced weathering and denudation processes at the supergene stage, very soluble gypsum and gypsum in dolomite were dissolved by fresh water, and none of the original salt and gypsum is now found in the weathering crust section. The original tight gypsumbearing dolomite evolved into a porous reservoir because the leaching of the original gypsum formed dissolution cavities. The overlying Permian sandstone and mudstone developed on the post-Carboniferous weathering crust. During the burial stage and especially the hydrocarbon generation stage, acid formation water produced dissolved new cavities and enlarged the original reservoir pores induced by dolomite dissolution. This further improved the reservoir. On the other hand, some pores would be plugged by the cavity filling of the overlying deposits and cementation of chemical deposits during the burial stage, making physical properties of local reservoirs worse. The coring data from Well CT-4 in the North Truva Oilfield show that the porosity of dolomite reservoir ranges from $7 \%$ to $39.2 \%$ and averages $16.9 \%$, and formation permeability ranges from 0.174 to $80.6 \mathrm{mD}$ and averages $16.04 \mathrm{mD}$. In general, dissolved cavities have an average diameter of $2-15 \mathrm{~mm}$ and an areal corrosion ratio of $2.5 \%$, indicating high quality dolomite reservoir with single well output above $200 \mathrm{t} / \mathrm{d}$.

\subsection{Dolomite reservoir of shoal facies - seepage reflux model}

At the end of the late Carboniferous, bioclastic shoal and platform edge shoal deposition of open platform facies dominated to the west of the Zhanazhol Oilfield, and intraplatform shoal deposition developed in restricted platform facies environments. There were mainly algae particle and granular limestone. The restricted sea was immediately adjacent to the inner side of the bioclastic shoals and around the intra-platform shoals, due to shallower water, higher salinity, gravity action and convection effects during regression periods. Hyper-saline seawater flowed downward or laterally into platform edge shoals and intra-platform shoals. When the $\mathrm{Mg} / \mathrm{Ca}$ ratio in seawater reached $5: 1$, dolomitization took place (Meyers et al, 1997; Montanez and Read, 1992). Granular dolomite formed as the result of metasomatic alternation of calcareous particles and interstitial matter, and those not replaced remained granular limestone. There were mainly algae particle and granular calcareous dolomite, bioclastic micritic calcareous dolomite and dolomitic limestone. After calcite was replaced by dolomite, the rock volume decreased by $13 \%$, and rock shrinkage formed pores. Simultaneously, new dissolved pores formed, the pre-existing pores were further dissolved and expanded. Reservoir physical properties were further improved, because residual calcite was dissolved by acid water generated in the dolomitization process. Due to the Hercynian movement and diagenesis of the overlying Permian mudstone after the Carboniferous sedimentary activities, further reformation 


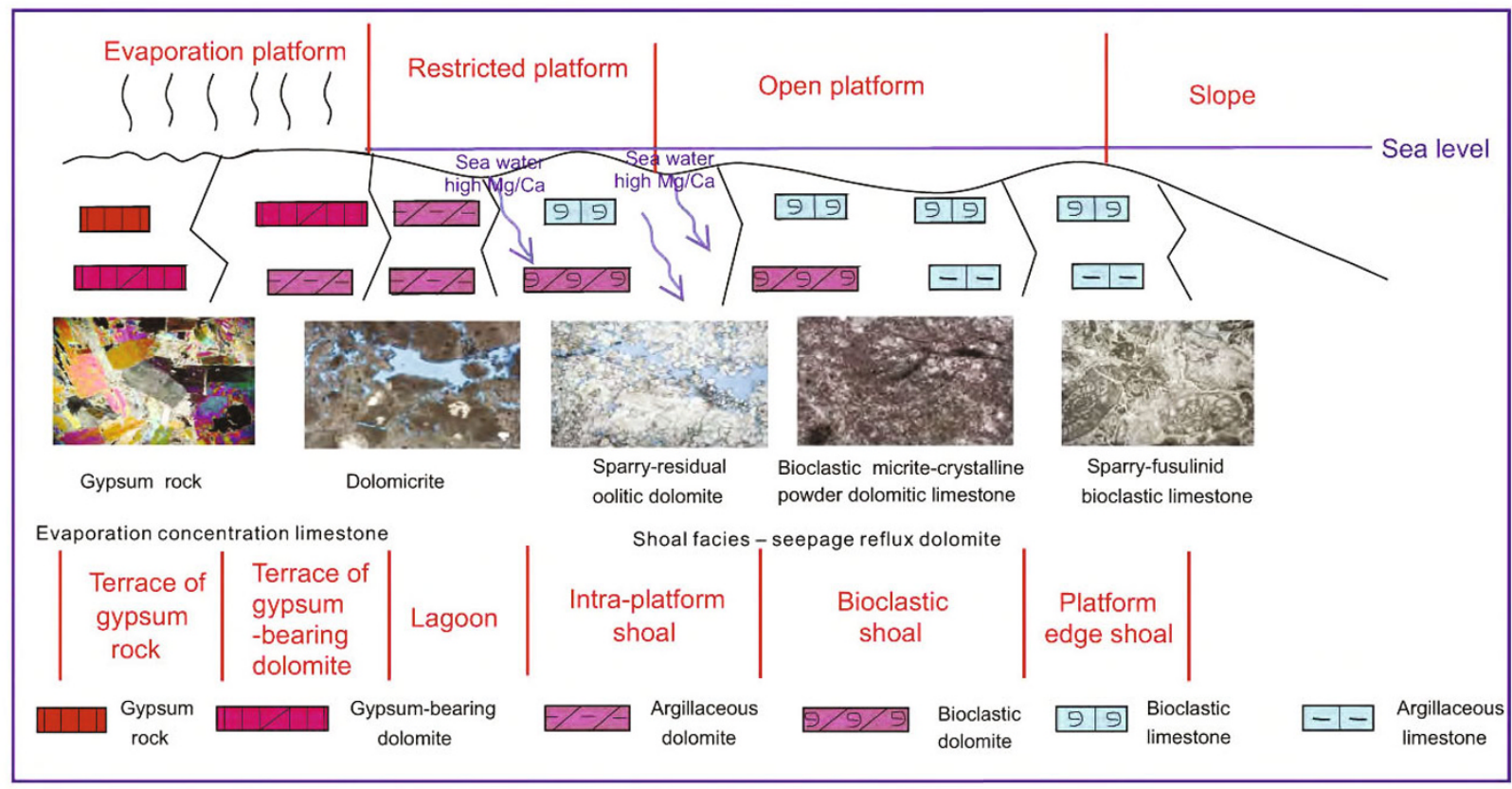

Fig. 9 Genetic models of dolomite in the Pre-Caspian Basin

of shoal facies - seepage reflux dolomite reservoirs formed earlier was completed, and the present dolomite reservoirs took shape (Fig. 9). In the middle and west of the Zhanazhol Oilfield, such dolomite reservoirs are developed. The reservoirs are mainly composed of dolomite, calcite dolomite interlayered with dolomitic limestone and limestone. Dolomite is controlled by granular dolomite with a particle content of about $65 \%$ and interstitial matter mainly of micritic grading. Crystalline dolomite has a particle content of $28 \%$ and good lamination, presenting a laminated granular formation. Its single layer is $1.5-15 \mathrm{~m}$ thick, reservoir porosity is $6 \%-13.7 \%$, formation permeability is $23-153 \mathrm{mD}$ and single well output is $2-60 \mathrm{t} / \mathrm{d}$.

\section{Conclusions}

The Carboniferous KT-I dolomite reservoir of Enbeksk Zharamysskaya Uplift Zone pre-salt sequence in the eastern margin of the Pre-Caspian Basin is the major hydrocarbon reservoir. Dolomite reservoirs in the study area are thick in the east and south and thin in the west and north. The dolomite is mainly of crystalline dolomite $(77.6 \%)$, dominated primarily by crystalline powder dolomite and micritic-crystalline powder dolomite and secondarily by granular dolomite $(16.8 \%)$, mostly bioclastic dolomite.

Stable carbon and oxygen isotopes analysis of dolomite shows that the $\delta^{18} \mathrm{O}$ values range from $-6.71 \%$ to $2.45 \%$ and average $0.063 \%$ (apparently larger than $-2.5 \%$ ), indicating low temperature evaporation genesis dolomite. Dolomite $\delta^{13} \mathrm{C}$ values range from $-1.6 \%$ to $5.94 \%$ and average $4.48 \%$, very similar to carbon stable isotope levels of Carboniferous seawater and unaffected by burial conditions.

Strontium stable isotope analysis data show that the ratio of ${ }^{87} \mathrm{Sr} /{ }^{86} \mathrm{Sr}$ ranges from 0.70829 to 0.70875 and averages 0.708365 , very consistent with that of the Carboniferous seawater. On average, dolomite has an excess Ca content of 9.1 mole $\%$. The degree of order of dolomite varies within a range of $0.336-0.504$ and averages 0.417 , judged to be a medium to slightly poor degree of order which is obviously smaller than that of burial dolomite.

There are two models proposed for the genesis of the Carboniferous KT-I dolomite in the study area. The models are based on comprehensive analysis of regional structure, deposition and diagenesis. The two models are 1) the evaporation concentration - weathering crust model and 2) the shoal facies - seepage reflux model. The former is mostly controlled by restricted platforms - evaporation platforms in a restricted sea and composed of dolomite and associated gypsum and mudstone. The latter is formed mainly in platform edge shoals and intra-platform shoals and controlled by dolomitization induced by high salinity seawater from adjacent restricted sea or evaporation platforms.

\section{References}

Allan J R and Wiggins W D. Dolomite reservoirs: Geochemical techniques for evaluating origin and distribution. AAPG Short Course Note Series. 1993. 36: 129-132

Burke W H, Denison R E, Hetherington E A, et al. Variation of seawater ${ }^{87} \mathrm{Sr} /{ }^{86} \mathrm{Sr}$ throughout Phanerozoic time. Geology. 1982. 10(10): 516519

Deng W F, Wei G $\mathbf{J}$ and Li X H. Online analysis of carbon and oxygen isotopic compositions of impure carbonate. Geochimica. 2005. 34(5): 494-500 (in Chinese)

Franchi I A, Wright I P, Gibson E K, et al. The laser microprobe: A technique for extracting carbon, nitrogen, and oxygen from solid samples for isotopic measurements. Journal of Geophysical Research. 1986. 91(B4): D514-D524

Guo F S, Pan J Y, Liu L Q, et al. Carbon and oxygen isotopic characteristics of carbonate rocks of Carboniferous-Permian in Jiangshan, Zhejiang Province. Geochimica. 2004. 33(1): 1-8 (in Chinese) 
Lohmann $\mathrm{K} \mathrm{C}$ and Walker J C G. The $\delta^{18} \mathrm{O}$ record of Phanerozoic abiotic marine calcite cements. Geophysical Research Letters. 1989. 16(4): 319-322

Luo P, Su L P, Luo Z, et al. Application of laser micro-sampling technique to analysis of $\mathrm{C}$ and $\mathrm{O}$ isotopes of oolitic dolomites in Feixianguan Formation, Northeast Sichuan. Geochimica. 2006. 35(3): 325-330 (in Chinese)

Lü Z C, Liu C Q, Liu J J, et al. Carbon, oxygen and strontium isotopic studies of the Huangboshuwan witherite deposit at Ziyang and the Wenyuhe witherite deposit at Zhushan, China. Geochimica. 2005. 34(6): 557-573 (in Chinese)

Meyers W J, Lu F H and Zachariah J K. Dolomitization by mixed evaporative brines and fresh water, upper Miocene carbonates, Nijar, Spain. Journal of Sedimentary Research. 1997. 67(5): 898912

Montanez I P and Read J F. Fluid-rock interaction history during stabilization of early dolomites, upper Knox Group (Lower Ordovician), U.S. Appalachians. Journal of Sedimentary Research. 1992. 62(5): 753-778

Palmer M R and Elderfield H. Sr isotope composition of sea water over the past 75 Myr. Nature. 1985. 314: 526-528

Peng J T, Hu R Z, Deng H L, et al. Strontium isotope geochemistry of the Xikuangshan antimony deposit, central Hunan. Geochimica. 2001. 30(3): 248-256 (in Chinese)

Popp B N, Anderson T F and Sandberg P A. Brachiopods as indicators of original isotopic compositions in some Paleozoic limestones. Geological Society of America Bulletin. 1986. 97(10): 1262-1269

Powell M D and Kyser T K. Analysis of $\delta^{13} \mathrm{C}$ and $\delta^{18} \mathrm{O}$ in calcite, dolomite, rhodochrosite and siderite using a laser extraction system. Chemical Geology. 1991. 94(1): 55-66

Qiang Z T, Ma D Y, Gu D Y, et al. The laser micro-sampling technique for analysis of isotope. Natural Gas Industry. 1996. 16(6): 86-89 (in Chinese)

Smith Jr L B. Origin and reservoir characteristics of Upper Ordovician Trenton-Black River hydrothermal dolomite reservoirs in New York. AAPG Bulletin. 2006. 90(11): 1691-1718

Wang K F and Chen J S. Constraints on the stable isotopic composition of sedimentary carbonates from the Tieling formation in the Yanshan region. Geochimica. 1993. 22(1): 10-17 (in Chinese)

Warren J. Dolomite: Occurrence, evolution and economically important associations. Earth Science Reviews. 2000. 52(1-3): 1-81

Zhang Y S. Mechanism of deep burial dolomitization of massive dolostones in the Middle Majiagou Group of the Ordovician, Ordos Basin. Acta Sedimentologica Sinica. 2000. 18(3): 425-430 (in Chinese)

Zhao Z P, Mou X Q and Chen L. Analysis on main diagenesis and controlling factors of Carboniferous carbonate reservoirs in the eastern margin of Pre-Caspian Basin. Geoscience. 2009. 23(5): 828834 (in Chinese)

(Edited by Hao Jie) 